\title{
Anxiety and depression in patients with chronic obstructive pulmonary disease and their relation to serum vitamin $D$ levels
}

\author{
Kronik obstrüktif akciğer hastalığı olan hastalarda anksiyete ve depresyon ile serum D vitamini \\ düzeyleri arasındaki ilişki \\ Derya KOCAKAYA, Sehnaz OLGUN YILDIZELI, Ozan KOCAKAYA, Huseyin ARIKAN, Emel ERYUKSEL, Berrin \\ CEYHAN
}

\begin{abstract}
Objectives: To determine whether serum vitamin D levels were related to the risk of anxiety and depression among patients with chronic obstructive pulmonary disease (COPD), as well as their spirometry parameters, disease severity, and other clinical findings.

Materials and Methods: Ninety-two stable patients with COPD aged over 18 years with no exacerbations in the previous month were included. Symptom severity was assessed using the modified Medical Research Council (mMRC) dyspnea scale and COPD Assessment Test (CAT) scores. Spirometry tests were performed and previous hospitalization histories were recorded to determine $\mathrm{ABCD}$ groups of the patients according to their combined COPD assessments. Their Body mass index, airflow Obstruction, Dyspnea and Exercise capacity (BODE) indices were calculated and the Hospital Anxiety and Depression Scale (HADS) was administered. Serum vitamin D levels were determined using immune electrochemiluminescence.

Results: According to the HADS scores, 16 patients (17.4\%) had the risk of anxiety and $29(31.5 \%)$ had the risk of depression. The risk of anxiety differed significantly ( $P=0.016$ Fischer's exact test $)$ between the ABCD groups. Anxiety scores were positively correlated with both mMRC $(r=0.315 ; P=0.002)$ and CAT $(r=0.445 ; P=0.000)$ scores. Similarly, depression scores correlated positively with mMRC ( $\mathrm{r}=$ $0.249 ; P=0.017)$ and CAT $(r=0.373 ; P=0.000)$ scores. Neither anxiety nor depression scores were significantly correlated with $\%$ of predicted FEV1. Serum vitamin D levels were inversely correlated with anxiety $(r=-0.215 ; P=0.039)$ and depression $(r=-0.244 ; P=0.019)$ scores. Anxiety scores were positively correlated with BODE although not statistically significantly $(r=0.199 ; P=0.058)$.

Conclusion: A negative correlation was revealed between serum vitamin D levels and HADS scores, and symptom scores were positively correlated to HADS scores, independent of \% of predicted FEV1.
\end{abstract}

Keywords: Anxiety, Depression, Vitamin D, Chronic obstructive pulmonary disease

Derya Kocakaya (可), Şehnaz Olgun Yıldızeli, Hüseyin Arıkan, Emel Eryüksel, Berrin Ceyhan

Department of Pulmonary and Critical Care Medicine, School of Medicine, Marmara University Hospital, Üst Kaynarca, Pendik, Istanbul, Turkey

e-mail:drderyagun@gmail.com

Ozan Kocakaya

Department of Internal Medicine, School of Medicine, Marmara University Hospital, Üst Kaynarca, Pendik, Istanbul, Turkey

Submitted / Gönderilme: 16.09.2017Ａccepted/Kabul: 02.11.2017
ÖZ

Amaç: Bu çalışmada kronik obstrüktif akciğer hastalığı (KOAH) olan hastalarda anksiyete ve depresyon riski ile D vitamini düzeyi, solunum fonksiyon test parametreleri, hastalığın ciddiyeti ve diğer klinik bulguları arasındaki ilişkinin gösterilmesi amaçlanmıştır.

Hastalar ve Yöntem: Son 1 ayda alevlenme geçirmemiş olan doksan iki stabil KOAH hastası çalışmaya dahil edilmiştir. Hastaların semptomları, modifiye Medical Research Council (mMRC) dispne skoru ve KOAH Değerlendirme Testi [COPD Assessment Test (CAT)] skoru ile değerlendirilmiş, solunum fonksiyon testleri yapılmış, hastane yatış öyküleri alınmış ve KOAH birleşik grupları belirlenmiştir. Beden kitle indeksi, Obstrüksiyon, Dispne ve Egzersiz kapasitesi (BODE) indeksleri hesaplanmış ve Hastane Anksiyete Depresyon Ölçeği (HADS) uygulanmıştır. Serum D vitamini düzeyleri ölçümü, elektrokemilüminesans immün ölçüm yöntemi ile yapılmıştır.

Bulgular: HADS ile değerlendirilen 16 hastada anksiyete riski (\%17.4) ve 29 hastada (\%31.5) depresyon riski olduğu gözlenmiş olup KOAH birleşik grupları arasında anksiyete riski açısından anlamlı fark saptanmıştır. ( $P=0,016$ Fisher's exact test $)$. Anksiyete skorlar1 ile hem mMRC $(r=0,315 ; P=0,002)$, hem de CAT $(r=0,445 ; P=0,000)$ skorları arasinda pozitif korelasyon tespit edilmiştir. Depresyon skorları ile mMRC $(r=0,249 ; P=0,017)$ ve CAT $(r=0,373 ; P=0,000)$ skorları arasında da pozitif korelasyon saptanmıştır. Ne anksiyete ne de depresyon skorları ile \%FEV1 değerleri arasında anlamlı ilişki saptanmamıştır. Hastaların D vitamini düzeyleri ile anksiyete $(r=-0,215 ; P=0,039)$ ve depresyon $(r=-0,244 ; P=0,019)$ skorları arasında negatif korelasyon olduğu görülmüştür. BODE indeksi ile anksiyete skorları arasında ise istatistiksel anlamlılığa ulaşmasa da, pozitif bir korelasyon olduğu $(r=0,199 ; P=0,058)$ gözlenmiştir.

Sonuç: KOAH hastalarında D vitamini düzeyleri ile anksiyete ve depresyon skorları arasında negatif bir ilişki saptanmış, ayrıca bu hastalarda \%FEV1' den bağımsız olarak semptom skorları ile anksiyete ve depresyon skorları arasında pozitif bir korelasyon olduğu gösterilmiştir.

Anahtar kelimeler: Anksiyete, Depresyon, D Vitamini, Kronik obstrüktif akciğer hastalığı 


\section{Introduction}

Chronic obstructive pulmonary disease (COPD) is a quite frequent, preventable, and treatable lung disease characterized by persistent respiratory symptoms and airway obstruction that develops upon exposure to harmful gasses or particles. Exacerbations and coexisting comorbidities contribute to disease severity [1]. It is one of the leading causes of morbidity and mortality worldwide and is a significant economic and social burden [2,3].

COPD most commonly emerges in middle aged or elderly individuals, often coexisting with other medical conditions, the most common of which are skeletal muscle weakness, malnutrition and other eating disorders, cachexia, cardiovascular diseases, endocrine abnormalities, anemia, anxiety and depression, as well as lung cancer. Comorbidities affect COPD severity and prognosis negatively [4].

Although anxiety and depression are common among patients with COPD, they are mostly untreated. Factors that contribute to anxiety and depression among patients with COPD are physical disability, long-term oxygen support requirement, low body mass index (BMI), severe dyspnea, $\%$ of predicted forced expiratory volume in 1 second (FEV1) below 50 and existing comorbidities [5].

A workshop report published in 2008 reported the prevalence of anxiety as $10-19 \%$ and depression as $10-42 \%$ among patients with COPD [5]. Other studies similarly documented a higher prevalence of anxiety and depression in patients with COPD when compared with the normal population $[6,7]$.

Studies that investigated the relation between the degree of pulmonary functional deterioration and anxiety and depression revealed no correlation between $\%$ of predicted FEV1 and the psychologic aspect of the disease. On the other hand, it has been shown that the presence of respiratory symptoms leads to severe anxiety and depression, and the presence of dyspnea is significantly correlated with anxiety and depression [8,9].

Results from studies that investigated the relation between serum vitamin $\mathrm{D}$ levels and the presence of anxiety and depression are conflicting. One study revealed that low serum vitamin D levels were associated with an increased prevalence of depression; however, an intervention of vitamin D replacement had no effect on symptoms of depression $[10,11]$. Another study revealed that patients with depression had lower serum vitamin D levels $(P=0.001)$, which were inversely correlated with symptom severity
[12]. Another study by Zhao et al., found no significant correlation between serum vitamin $\mathrm{D}$ levels and depression [13].

In this study, we aimed to determine whether serum vitamin D levels were related to the risk of anxiety and depression, as well as severity of symptoms, COPD stage, and other clinical properties.

\section{Patients and Methods}

The study was conducted in Marmara University Medical School, Department of Pulmonary and Critical Care Medicine, after being approved by the local ethics committee. Ninety-two patients who were admitted to outpatient clinics between November 1st, 2013, and February 28th, 2014, and were diagnosed as having COPD through pulmonary function test criteria of FEV1 to forced vital capacity (FVC) ratio was less than 0.70 and negative reversibility tests, who had no history of exacerbation within the previous month, and were aged over 18 years, were included in the study.

The included patients provided written consent, performed spirometry, and their modified Medical Research Council (mMRC) dyspnea scale and COPD Assessment Test (CAT) scores were calculated. Their COPD exacerbation numbers were questioned and combined COPD groups were determined [1].

In accordance with the American Thoracic Society (ATS) criteria, spirometry testing was performed three times via an MIR Spirolab II (Medical International Research (Rome, Italy Serial No: 149491103403) device and the best of the three measurements was recorded [14]. Reversibility was tested after inhalation of 4 puffs (400 micrograms) of salbutamol and repetition of the test 15 minutes later to measure FEV1 (\% and liter [1t]), FVC ( $\%$ and $1 \mathrm{t})$ and FEV1/ FVC (\%). Severities of dyspnea were stratified from 0 to 4 using the mMRC scale [15]. The validated Turkish version of the CAT was applied to determine the level of symptom severity [16].

The risk of anxiety and depression was determined using the validated Turkish version of the HADS questionnaire [17], which consists of 14 questions where odd-numbered questions are related with anxiety and even-numbered questions are concerned with depression. HADS is a fourpoint Likert scale and a form of self - report where each item is graded from 0 to 3 . The Turkish version of the scale has a cut-off of 10 points for anxiety and 7 points for depression. 
Patients with scores above these thresholds were considered to be in risk groups.

When calculating Body mass index, airflow Obstruction, Dyspnea and Exercise capacity (BODE) indices, the factors taken into account were BMI, \% of predicted FEV1 from pulmonary function tests, $\mathrm{mMRC}$ scores, and 6-minute walk distance [18]. The 6-minute walk test was performed according to the ATS recommendations [19].

\section{Statistical Analysis}

All statistical analyses were performed using version 17.0 of SPSS. Categorical variables were compared using the Chi-square test and Fisher's exact test. Chi-square test was used for $2 \times 2$ contingency tables. Normally distributed variables were analyzed using One-way ANOVA and variables that were not distributed normally were analyzed using the Kruskal-Wallis test. Correlation analyses were run using Pearson's correlation test for normally distributed data, and Spearman's correlation test for those that were not. In all analyses, a $P$ value $<0.05$ was considered as significant.

\section{Results}

Ninety-two stable patients with COPD were included in the study. Eighty-one (88\%) of the participants were male and $11(12 \%)$ were female, and the mean age was $61.5 \pm 10.5$ years. When distributed among the combined COPD assessment groups, 31 (33.7\%), 41 (44.6\%), 5 (5.4\%), and $15(16.3 \%)$ patients were placed in groups A, B, C, and D, respectively. The sociodemographic and clinical variables of the patients according to risks of anxiety and depression are presented in Table I.

According to the HADS scores, $16(17.4 \%)$ and 29 $(31.5 \%)$ patients were detected above the cut-off point for

Table I. Sociodemographic and clinical variables of patients according to risk of anxiety and depression.

\begin{tabular}{|c|c|c|c|c|c|c|}
\hline & $\begin{array}{l}\text { Anxiety } \\
\text { score } \geq 10\end{array}$ & $\begin{array}{l}\text { Anxiety score } \\
<10\end{array}$ & $P$ value & $\begin{array}{l}\text { De pression } \\
\text { score } \geq 7\end{array}$ & $\begin{array}{l}\text { Depression } \\
\text { score }<7\end{array}$ & $P$ value \\
\hline Age $($ mean \pm SD) & $60.5 \pm 11.5$ & $61.6 \pm 10.4$ & 0.787 & $63.9 \pm 9.2$ & $60.3 \pm 10.9$ & 0.939 \\
\hline $\begin{array}{l}\text { Sex } \\
\text { Female (n) } \\
\text { Male (n) }\end{array}$ & $\begin{array}{l}3 \\
13\end{array}$ & $\begin{array}{l}8 \\
68\end{array}$ & 0.357 & $\begin{array}{l}5 \\
24\end{array}$ & $\begin{array}{l}6 \\
57\end{array}$ & 0.289 \\
\hline $\begin{array}{l}\text { FEV1/FVC } \\
\text { (median) } \\
(\text { min.-max.) }\end{array}$ & $\begin{array}{l}0.51 \\
0.33-0.69\end{array}$ & $\begin{array}{l}0.62 \\
0.37-0.70\end{array}$ & 0.400 & $\begin{array}{l}0.56 \\
0.33-0.68\end{array}$ & $\begin{array}{l}0.64 \\
0.36-0.70\end{array}$ & 0.300 \\
\hline $\begin{array}{l}\text { FEV1(\% pred) } \\
(\text { mean } \pm \text { SD })\end{array}$ & $56.5 \pm 21.3$ & $66.8 \pm 21.3$ & 0.43 & $61.5 \pm 21.7$ & $66.2 \pm 21.6$ & 0.400 \\
\hline $\begin{array}{l}\text { CAT Score } \\
\text { (median) } \\
\text { (min.-max.) }\end{array}$ & $\begin{array}{l}22.5 \\
7-33\end{array}$ & $\begin{array}{l}10.5 \\
0-28\end{array}$ & 0.043 & $\begin{array}{l}19 \\
3-33\end{array}$ & $\begin{array}{l}11 \\
0-28\end{array}$ & 0.466 \\
\hline $\begin{array}{l}\text { BODE index } \\
\text { (median) } \\
\text { (min.-max.) }\end{array}$ & $\begin{array}{l}3.5 \\
0-7\end{array}$ & $\begin{array}{l}1 \\
0-8\end{array}$ & 0.265 & $\begin{array}{l}3 \\
0-7\end{array}$ & $\begin{array}{l}1 \\
0-8\end{array}$ & 0.479 \\
\hline $\begin{array}{l}\text { Vitamin D } \\
\text { levels (ng/ml) } \\
\text { (median) } \\
\text { (min.-max.) }\end{array}$ & $\begin{array}{l}8.6 \\
3-20.3\end{array}$ & $\begin{array}{l}9.9 \\
3-45.4\end{array}$ & 0.456 & $\begin{array}{l}8.3 \\
3-32.3\end{array}$ & $\begin{array}{l}10.2 \\
3-45.4\end{array}$ & 0.50 \\
\hline
\end{tabular}


anxiety and depression, respectively. The risk of anxiety differed significantly $(P=0.016$ Fisher's exact test) between the combined COPD groups, whereas that of depression did not differ significantly $(P=0.129$ Fisher's exact test) (Table II and Figure 1).

Table II. The number of patients with anxiety and depression risk among the combined COPD groups.

\begin{tabular}{|l|l|l|l|l|l|}
\hline & \multicolumn{5}{|l|}{ Combined COPD Assessment } \\
\hline & $\begin{array}{l}\text { Group } \\
\text { A }\end{array}$ & $\begin{array}{l}\text { Group } \\
\text { B }\end{array}$ & $\begin{array}{l}\text { Group } \\
\text { C }\end{array}$ & $\begin{array}{l}\text { Group } \\
\text { D }\end{array}$ & $\begin{array}{l}\text { Fischer's } \\
\text { exact test } \\
\boldsymbol{P} \text { value }\end{array}$ \\
\hline Anxiety score $\geq \mathbf{1 0}$ & 1 & 10 & 0 & 5 & \multirow{2}{*}{$\mathbf{0 . 0 1 6}$} \\
\hline Anxiety score $<\mathbf{1 0}$ & 30 & 31 & 5 & 10 & \multirow{2}{*}{$\mathbf{0 . 1 2 9}$} \\
\hline Depression score $\geq 7$ & 8 & 13 & 0 & 8 & \\
\hline Depression score $<7$ & 23 & 28 & 5 & 7 & \\
\hline
\end{tabular}

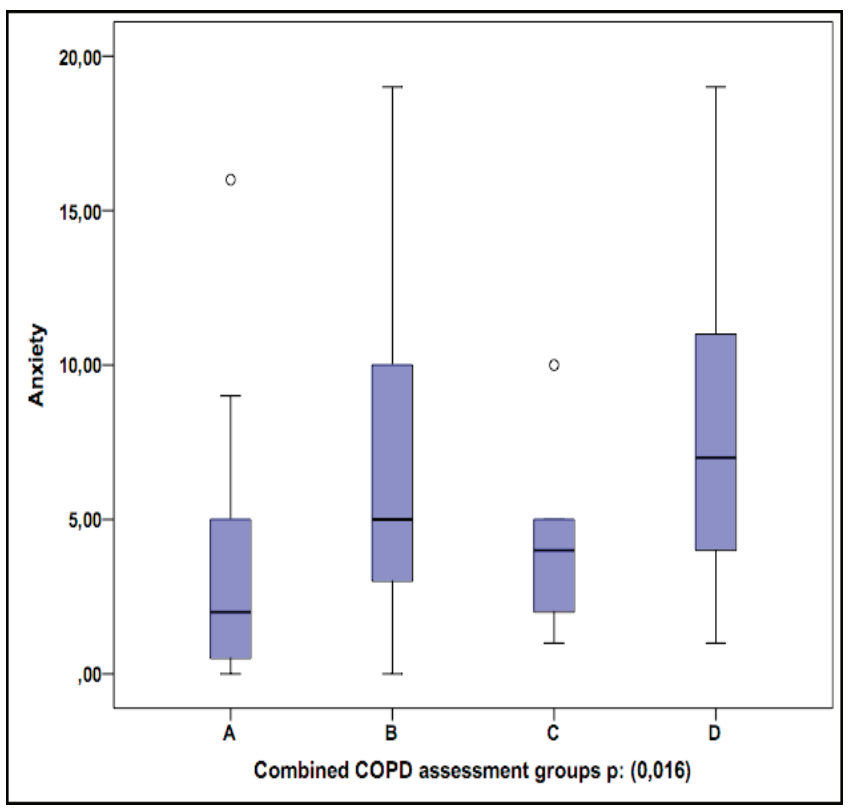

Figure 1. Distribution of the number of patients with anxiety risk among $\mathrm{ABCD}$ groups

When serum vitamin D levels and their relations to anxiety and depression scores were analyzed, vitamin D levels were found to be negatively correlated with scores of both anxiety $(r=-0.215 ; P=0.039)$ and depression $(r=-$ $0.244 ; P=0.019$ ) (Figure 2).
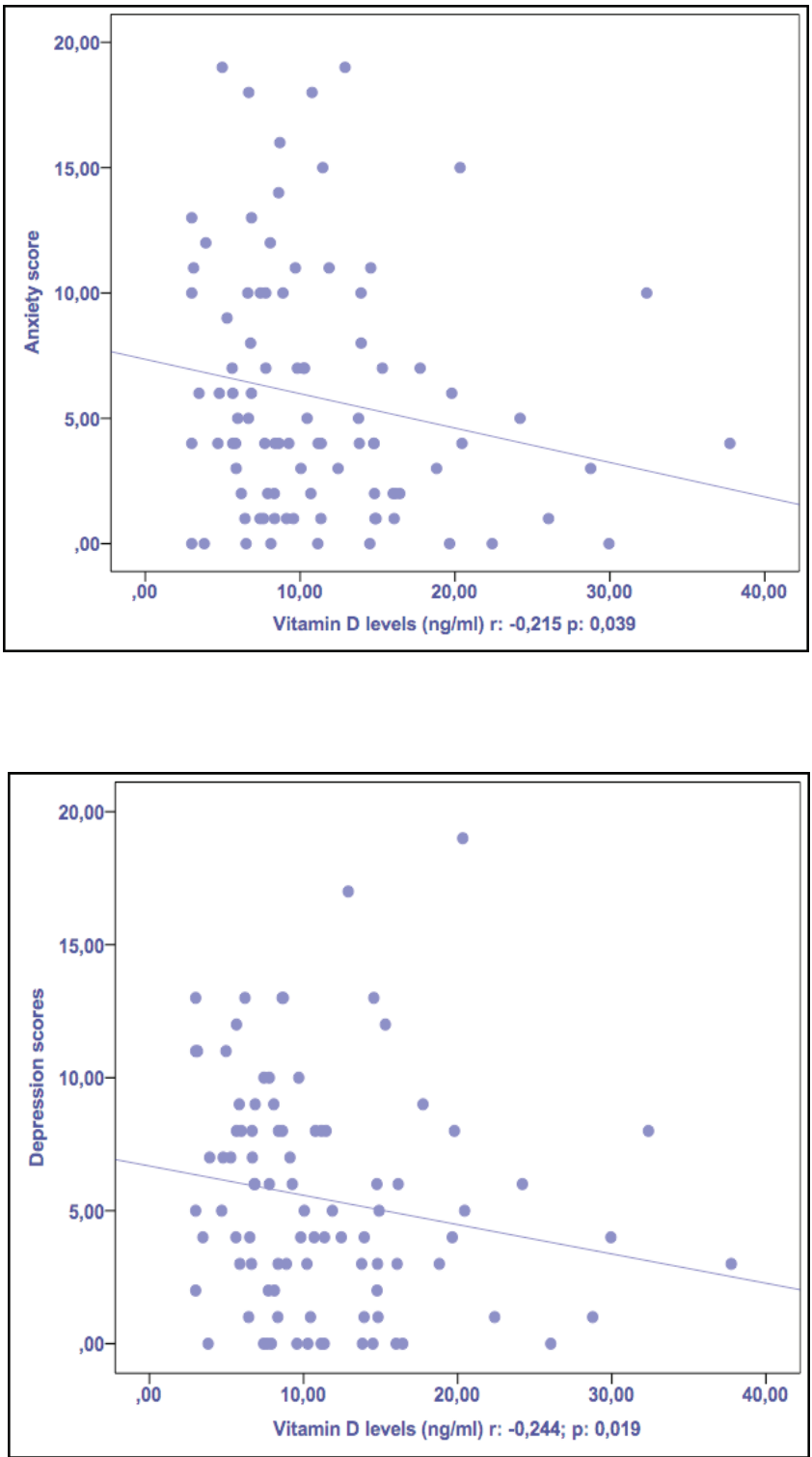

Figure 2. Correlation between anxiety and depression scores and vitamin D levels of COPD patients

Anxiety scores were positively correlated with both $\operatorname{mMRC}(r=0.315 ; P=0.002)$ and CAT scores $(r=0.445$; $P=0.000$ ) (Figure 3). Similarly, depression scores were also positively correlated with both $\mathrm{mMRC}(r=0.249 ; P=0.017)$ and CAT scores ( $r=0.373 ; P=0.000$ ) (Figure 4). Neither anxiety nor depression scores had any significant relation with $\%$ of predicted FEV1 values.

Although, it did not reach statistical significance ( $r=0.199 ; P=0.058$ ), there was a positive correlation between BODE indices and the anxiety scores of the patients. 


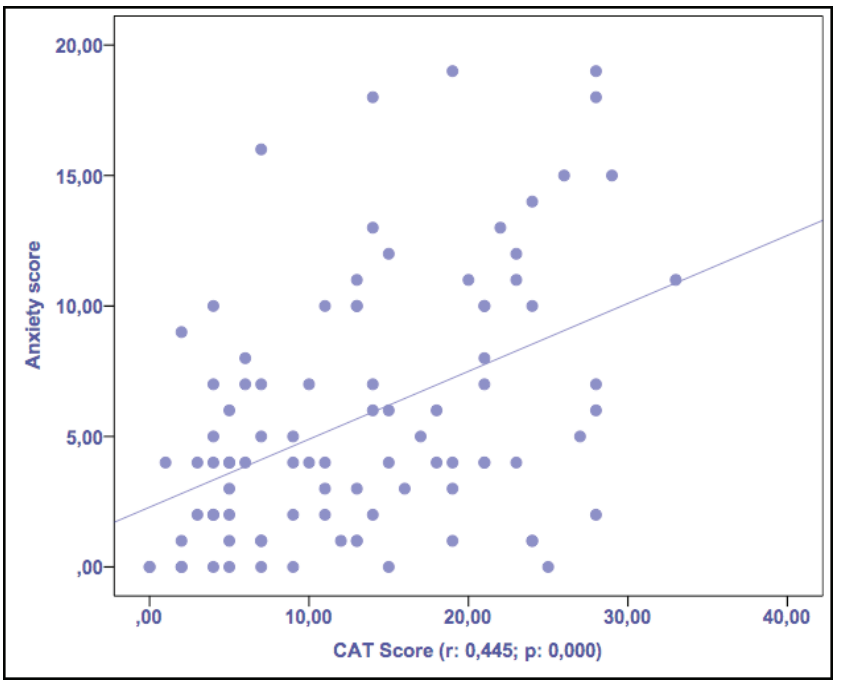

Figure 3. Correlation between anxiety scores and CAT scores of COPD patients

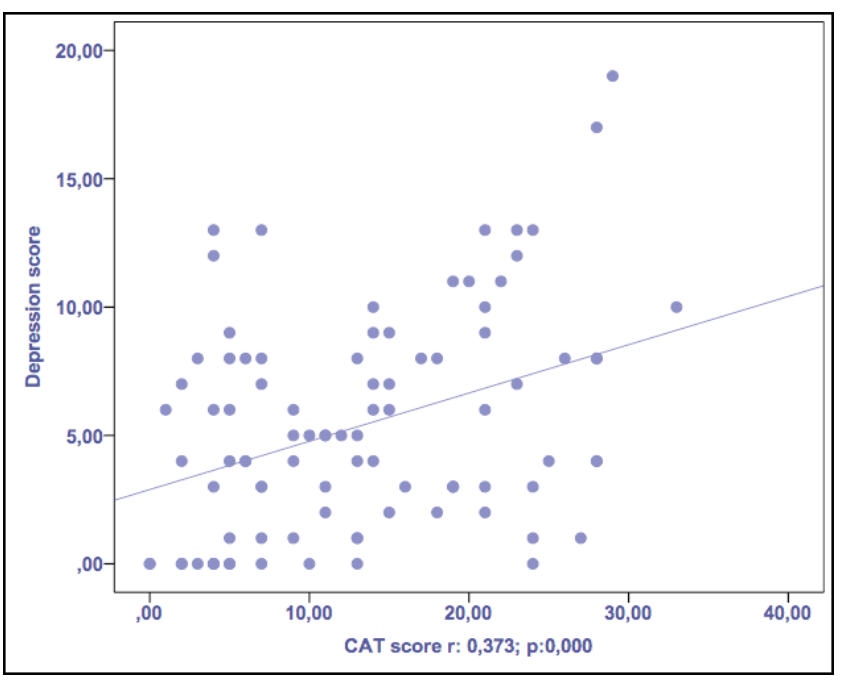

Figure 4. Correlation between depression scores and CAT scores of COPD patients

\section{Discussion}

At the end of this study, we found that patients with COPD who had low serum vitamin D levels had higher anxiety and depression scores when assessed with HADS. Furthermore, patients' anxiety and depression scores correlated positively with their symptom scores irrespective of their \% of predicted FEV1 values. In accordance to these findings, the BODE index, which determines the clinical situation of the patients, was positively correlated to anxiety scores; however, this did not reach statistical significance.
In our study, the prevalence of anxiety and depression risk was found to be higher than in the normal population, consistent with other studies [5-9]. More importantly, our study established a negative correlation between anxiety and depression scores and serum vitamin D levels, as well as a positive correlation between symptom scores and anxiety risk between and depression scores. Furthermore, our study showed that a statistically significant difference in terms of anxiety risk between $\mathrm{ABCD}$ groups, exists more prominently in groups B and D.

Epidemiologic studies have revealed the emerging prevalence of vitamin D deficiency throughout the world and most prominently in North America and West Europe [20,21]. There are no definitive data regarding vitamin D deficiency in Turkey; however, it is reported at between $30-75 \%$ [22]. Although, Turkey lies in an advantageous geographic location in terms of sunlight exposure, reasons such as dressing habits, inadequate consumption of vitamin $\mathrm{D}$ fortified foods, and a limited practice of outdoor activities leads to an increased prevalence of vitamin D insufficiency [23]. Many studies were performed about the prevalence of vitamin D insufficiency in patients with COPD. A study by Forli et al. determined a vitamin $\mathrm{D}$ deficiency prevalence of over $50 \%$ in their cohort of patients in line for lung transplantation, most of whom were diagnosed as having COPD [24]. Another cross sectional study by Franco et al. was conducted on 49 patients with COPD where only $3(6 \%)$ had adequate (>30 ng/mL) levels of vitamin D; 29 (59\%) had inadequacy (21-29 ng/mL) and 17 (35\%) had deficiency $(<20 \mathrm{ng} / \mathrm{mL})$ [25]. Another study that was conducted on 462 patients with COPD found that $44.8 \%$ of the patients have inadequate levels of vitamin $\mathrm{D}$ and $30.5 \%$ were deficient [26]. In our study, the prevalence of vitamin D deficiency was quite high because $89.1 \%$ of the 92 patients studied were deficient and 7.6\% had inadequate vitamin D levels; only 3 patients (3.2\%) had sufficient levels of vitamin D.

Our study revealed vitamin D levels were correlated negatively with both anxiety and depression scores. Few studies have been conducted exploring the relation between levels of vitamin D and anxiety and depression; however, a study by Persson et al. revealed a statistically significant relationship between serum vitamin $\mathrm{D}$ levels and the presence of depression in 403 patients with COPD [27].

Many studies conducted among patients with COPD showed that the prevalence of anxiety and depression was higher in patients with COPD when compared with the normal population. Parallel to the current medical literature, 
our study identified the prevalence of anxiety as $17.4 \%$ and depression as $31.5 \%$ in patients with COPD [5-8].

Pulmonary impairment in COPD and emotional responses secondary to respiratory diseases cause dyspnea and physical inability, which further cause physical deconditioning, and social isolation leading to anxiety and depression [28]. It is known that cigarette smoking, inflammation, and hypoxia have potential effects on the development of depression in patients with COPD but the most important predicting factors of depression are diminished quality of life and symptom severity [29]. Consistent with our findings a recent study reports higher anxiety and depression scores in more symptomatic patients with COPD [9].

Our study did not yield a relation between $\%$ of predicted FEV1 and the risk of anxiety and depression; however, there are conflicting studies regarding the presence of a correlation $[9,30,31]$.

In addition to \% of predicted FEV1 values, the BODE index evaluates the clinical status of the patients by taking symptoms and exercise capacities into account. In our study, the relationship between BODE indices and anxiety scores showed a positive correlation that approached but did not reach statistical significance. In the current medical literature, many studies demonstrated that the BODE index correlated better with anxiety and depression than \% of predicted FEV1 [32,33].

The most important shortcoming of our study is its population size and the lack of a control group, which limits the comparison of anxiety and depression risk with the normal population. We may also assume the reason that the relation between BODE indices and anxiety and depression scores approached but could not reach statistical significance was the small sample size. Another limitation of the study is that we could only evaluate serum vitamin D levels during winter months; thus, could not take seasonal variances into account.

In conclusion, this study, which was conducted on a small number of patients, demonstrates serum vitamin $\mathrm{D}$ levels are very low in patients with COPD, and these low levels of vitamin D are negatively correlated with anxiety and depression scores. The high risk of anxiety and depression among patients with COPD should caution physicians to be more aware of these in the clinical setting. In addition, the positive correlation between anxiety and depression scores and symptom scores should alert us to consider the psychological comorbidities of the patients in terms of achieving better symptom control.

\section{References}

1. Global strategy for the diagnosis, management, and prevention of chronic obstructive pulmonary disease / 2018 Report. Accessed: 5 October, 2017 Available at: http://www. goldcopd.org.

2. Mathers CD, Loncar D. Projections of global mortality and burden of disease from 2002 to 2030. PLoS Med 2006; 3: e442. doi: 10.1371/journal.pmed.0030442

3. Lopez AD, Shibuya K, Rao C, et al. Chronic obstructive pulmonary disease: current burden and future projections. Eur Respir J 2006; 27: 397-412. doi: 10.1183/09031936.06.00025805

4. Barnes PJ, Celli BR. Systemic manifestations and comorbidities of COPD. Eur Respir J 2009; 33: 1165-85. doi: 10.1183/09031936.00128008

5. Maurer J, Rebbapragada V, Borson S, et al. Anxiety and depression in COPD: current understanding, unanswered questions, and research needs. Chest 2008; 134(4 Suppl): 43S-56S. doi: 10.1378/chest.08-0342

6. Hynninen KM, Breitve MH, Wiborg AB, Pallesen S, Nordhus IH. Psychological characteristics of patients with chronic obstructive pulmonary disease: a review. J Psychosom Res 2005; 59: 429-43. doi: 10.1016/j.jpsychores.2005.04.007

7. Di Marco F, Verga M, Reggente M, et al. Anxiety and depression in COPD patients: The roles of gender and disease severity. Respir Med 2006; 100: 1767-74. doi: 10.1016/j. rmed.2006.01.026

8. Cleland JA, Lee AJ, Hall S. Associations of depression and anxiety with gender, age, health-related quality of life and symptoms in primary care COPD patients. Fam Pract 2007; 24: 217-23. doi: 10.1093/fampra/cmm009

9. Pascal OI, Trofor AC, Lotrean LM, Filipeanu D, Trofor L. Depression, anxiety and panic disorders in chronic obstructive pulmonary disease patients: correlations with tobacco use, disease severity and quality of life. Tob Induc Dis 2017; 15: 23. doi: 10.1186/s12971-017-0128-9

10. Kjaergaard $M$, Waterloo $\mathrm{K}$, Wang CE, et al. Effect of vitamin D supplement on depression scores in people with low levels of serum 25-hydroxyvitamin D: nested case-control study and randomised clinical trial. Br J Psychiatry 2012; 201: 3608. doi: 10.1192/bjp.bp.111.104349

11. Sanders KM, Stuart AL, Williamson EJ, et al. Annual high-dose vitamin D3 and mental well-being: randomised controlled trial. Br J Psychiatry 2011; 198: 357-64. doi: 10.1192/bjp.bp. 110.087544

12. Milaneschi Y, Hoogendijk W, Lips P, et al. The association between low vitamin D and depressive disorders. Mol Psychiatry 2014;19:444-51. doi: 10.1038/mp.2013.36

13. Zhao G, Ford ES, Li C, Balluz LS. No associations between serum concentrations of 25-hydroxyvitamin D and parathyroid hormone and depression among US adults. Br J Nutr 2010; 104: 1696-702. doi: 10.1017/S0007114510002588 
14. Miller MR, Hankinson J, Brusasco V, et al. Standardisation of spirometry. Eur Respir J 2005; 26: 319-38. doi: 10.1183/09031936.05.00034805

15. Bestall JC, Paul EA, Garrod R, et al. Usefulness of the Medical Research Council (MRC) dyspnoea scale as a measure of disability in patients with chronic obstructive pulmonary disease. Thorax 1999; 54: 581-6.

16. Yorgancioğlu A, Polatli M, Aydemir Ö, et al. KOAH değerlendirme testinin Türkçe geçerlilik ve güvenilirliği. Tuberk Toraks 2012; 60: 314-320.

17. Aydemir Ö, Güvenir T, Küey L, Kültür S. Hastane anksiyete ve depresyon ölçeği Türkçe formunun geçerlilik ve güvenilirliği. Türk Psikiyatri Dergisi 1997; 8: 280-7.

18. Celli BR, Cote CG, Marin JM, et al. The body-mass index, airflow obstruction, dyspnea, and exercise capacity index in chronic obstructive pulmonary disease. N Engl J Med 2004; 350: 1005-12. doi: 10.1056/NEJMoa021322

19. ATS statement: guidelines for the six-minute walk test. Am J Respir Crit Care Med 2002; 166: 111-7. doi: 10.1164/ ajrccm.166.1.at1102

20. Henry HL, Bouillon R, Norman AW, et al. 14th Vitamin D Workshop consensus on vitamin D nutritional guidelines. J Steroid Biochem Mol Biol 2010; 121: 4-6. doi: 10.1016/j. jsbmb.2010.05.008

21. Raiten DJ, Picciano MF. Vitamin D and health in the 21st century: bone and beyond. Executive summary. Am J Clin Nutr 2004; 80(6 Suppl): 1673S-7S. doi:

22. Atli T, Gullu S, Uysal AR, Erdogan G. The prevalence of Vitamin D deficiency and effects of ultraviolet light on Vitamin D levels in elderly Turkish population. Arch Gerontol Geriatr 2005; 40: 53-60. doi: 10.1016/j.archger.2004.05.006

23. Hekimsoy Z, Dinc G, Kafesciler S, et al. Vitamin D status among adults in the Aegean region of Turkey. BMC Public Health 2010; 10: 782. doi: 10.1186/1471-2458-10-782

24. Forli L, Bjortuft O, Boe J. Vitamin D status in relation to nutritional depletion and muscle function in patients with advanced pulmonary disease. Exp Lung Res 2009; 35: 524-38.
25. Franco CB, Paz-Filho G, Gomes PE, et al. Chronic obstructive pulmonary disease is associated with osteoporosis and low levels of vitamin D. Osteoporos Int 2009; 20: 1881-7. doi: 10.1007/s00198-009-0890-5

26. Holmgaard DB, Mygind LH, Titlestad IL, et al. Serum vitamin $\mathrm{D}$ in patients with chronic obstructive lung disease does not correlate with mortality-results from a 10-year prospective cohort study. PLoS One 2013; 8: e53670. doi: 10.1371/journal.pone.0053670

27. Persson LJ, Aanerud M, Hiemstra PS, et al. Chronic obstructive pulmonary disease is associated with low levels of vitamin D. PLoS One 2012; 7: e38934. doi: 10.1371/ journal.pone. 0038934

28. Hill K, Geist R, Goldstein RS, Lacasse Y. Anxiety and depression in end-stage COPD. Eur Respir J 2008; 31: 667 77. doi: 10.1183/09031936.00125707

29. Hanania NA, Mullerova H, Locantore NW, et al. Determinants of depression in the ECLIPSE chronic obstructive pulmonary disease cohort. Am J Respir Crit Care Med 2011; 183: 60411. doi: 10.1164/rccm.201003-0472OC

30. Horita N, Kaneko T, Shinkai M, et al. Depression in Japanese patients with chronic obstructive pulmonary disease: a cross-sectional study. Respir Care 2013; 58: 1196-203. doi: 10.4187/respcare. 02065

31. Iguchi A, Senjyu H, Hayashi Y, et al. Relationship between depression in patients with COPD and the percent of predicted FEV(1), BODE index, and health-related quality of life. Respir Care 2013; 58: 334-9. doi: 10.4187/respcare.01844

32. Funk GC, Kirchheiner K, Burghuber OC, Hartl S. BODE index versus GOLD classification for explaining anxious and depressive symptoms in patients with COPD - a crosssectional study. Respir Res 2009; 10: 1. doi: 10.1186/14659921-10-1

33. Gonzalez-Gutierrez MV, Guerrero Velazquez J, Morales Garcia C, et al. Predictive Model for Anxiety and Depression in Spanish Patients with Stable Chronic Obstructive Pulmonary Disease. Arch Bronconeumol 2016; 52: 151-7. doi: 10.1016/j.arbres.2015.09.003 